\title{
STILISASI HEWAN PRASEJARAH DALAM BENTUK SENJATA KAPAK
}

\author{
Ahmad Prasetya Hady *)
}

\begin{abstract}
ABSTRAKSI
Sejak fosil dinosaurus pertama dikenali pada awal abad sembilan belas, rangka dinosaurus yang dirangkai menjadi pertunjukan yang poluler di museum-museum di seluruh dunia. Dinosaurus menjadi budaya dunia dan terus populer. Mereka menjadi topik di buku-buku terlaris dan film-film paling dikenal Jurassic Park, dan penemuan-penemuan baru secara teratur diungkapkan di media. Berbagai kemampuan itu dapat dilihat melalui bentuk adaptasi dalam memodifikasi tubuh dan prilaku. Keunikan karakter dinosaurus ini juga bila ditelisik lebih lanjut merupakan suatu bentuk ekspresi prilaku yang berbeda-beda. Setiap dinosaurus memiliki wujud bentuk yang belum pasti karena sampai saat ini memang belum ada bentuk yang secara pasti , hal ini membuat suatu peluang imajinatif untuk menafsirkan berbagai bentuk yang ada.

Metode yang digunakan dalam pembuatan karya seni ini menggunakan teori dari Gustami dengan 3 tahap 6 langkah dalam pembuatan karya seni. Dimulai dari eksplorasi tradisi daerah Banyuwangi, Perancangan karya yang akan dibuat, dan perwujudanya ke dalam karya senjata kapak. Dalam proses penciptaan ini digunakan pendekatan seperti estetik, simiotik dan ergonomis yang disesuaikan dengan bentuk karya yang diwujudkan.

Karya seni dan simbolisme kehidupan merupakan unsur penting pada karya ini. Komposisi ubahan inilah yang dirasa mampu membuat nilai artistik dari karya kapak ini muncul. Setiap audience yang melihat karya ini tentunya akan melihat konsep pemahaman terhadap unsur visual dalam bentuk baru seperti terangkum pada satu kemasan yang artistik. Masingmasing dari karya ini memiliki karakteristik yang berbeda dan disesuaikan dengan nilai-nilai dan pesan yang ada di dalamnya namun secara utuh karya ini memiliki satu garis besar visual tentang pesan simbolisme itu sendiri.
\end{abstract}

Kata Kunci : Senjata Kapak, Dinosaurus, Hewan Prasejarah, Simbolisme,

\section{PENDAHULUAN}

$\begin{array}{ll}\begin{array}{r}\text { Dinosaurus atau dalam bahasa } \\ \text { Yunani "deinosauros" adalah hewan }\end{array} & \begin{array}{l}\text { sekarang telah diklasifikasikan sebagai } \\ \text { dinosaurus. Penemuan burung primitif }\end{array} \\ \text { bertulang belakang yang dominan di } & \text { tahun } 1861 \text { Archaeopteryx pertamakalinya } \\ \text { ekosistem darat selama lebih dari } 160 \text { juta } & \text { memberi petunjuk kekerabatan erat antara } \\ \text { tahun, dari periode Trias Tua (sekitar } 230 & \text { dinosaurus dan burung. Selain adanya } \\ \text { juta tahun yang lalu) sampai dengan akhir } & \text { kesan bulu yang memfosil, Archaeopteryx } \\ \text { periode Kapur (sekitar } 65 \text { juta tahun yang } & \text { sangat mirip dinosaurus pemangsa } \\ \text { lalu), ketika banyak dari mereka punah pada } & \text { berukuran kecil Compsognathus. Sejak itu } \\ \text { peristiwa kepunahan Kapur-Tersier. } & \text { penelitian telah mengidentifikasi } \\ \text { Sepuluh ribuan jenis burung yang hidup } & \text { dinosaurus theropoda paling mungkin }\end{array}$

*AHMAD PRASTYA HADY, (Prastabejo@gmail.com), Mahasiswa Pasca Sarjana Institut Seni Indonesia Yogyakarta 
sebagai moyang langsung dari burung kebanyakan paleontolog sekarang menganggap burung sebagai satu-satunya dinosaurus yang masih bertahan, dan beberapa menyarankan bahwa dinosaurus dan burung mesti dikelompokkan dalam satu kelas biologi. Selain burung, buaya adalah kerabat dekat lain dari dinosaurus yang bertahan sampai kini.. Seperti dinosaurus dan burung, buaya juga anggota Archosauria, kelompok reptil yang muncul pertama kali pada periode sangat tua dan mendominasi pada periode Trias tengah. Selama paruh pertama dari abad ke 20, banyak komunitas ilmuwan percaya dinosaurus sebagai hewan berdarah dingin yang bodoh dan lambat. Namun, banyak penelitian yang dilakukan sejak tahun 1970 an (disebut renaisans dinosaurus) telah mendukung pandangan bahwa dinosaurus adalah binatang yang aktif dengan metabolisme yang tinggi dan adaptasi yang beragam untuk interaksi sosial. Perubahan yang dihasilkan pada pemahaman ilmiah tentang dinosaurus lambat laun tersaring menjadi kesadaran populer. Sejak fosil dinosaurus pertama dikenali pada awal abad sembilan belas, rangka dinosaurus yang dirangkai menjadi pertunjukan yang poluler di museum-museum di seluruh dunia. Dinosaurus menjadi budaya dunia dan terus populer. Mereka menjadi topik di buku-buku terlaris dan film-film paling dikenal Jurassic Park, dan penemuanpenemuan baru secara teratur diungkapkan di media Istilah "dinosaurus" (Inggris, dinosaur) dikemukakan tahun 1842 oleh Sir Richard Owen dan bersal dari bahasa Yunani deinos "mengerikan, kuat, hebat" (sauros) "kadal".
Dari berbagai daya tarik tentang dinosaurus yang telah diungkapkan sayangnya di Indonesia ketertarikan tentang berbagai hal tentang dinosaurus kurang diminati. Padahal hewan-hewan prasejarah ini memiliki fakta-fakta unik dibalik kemampuanya dalam bertahan hidup dibumi. Berbagai kemampuan itu dapat dilihat melalui bentuk adaptasi dalam memodifikasi tubuh dan prilaku. Keunikan karakter dinosaurus ini juga bila ditelisik lebih lanjut merupakan suatu bentuk ekspresi prilaku yang berbeda-beda. Setiap dinosaurus memiliki wujud bentuk yang belum pasti karena sampai saat ini memang belum ada bentuk yang secara pasti, hal ini membuat suatu peluang imajinatif untuk menafsirkan berbagai bentuk yang ada. Sehingga menjadi ketertarikan tersendiri bagi penulis untuk mengangkat bentuk dinosaurus kedalam karya seni baru yang menarik. Agar dapat membuat karya seni yang dimaksud lebih menarik untuk ditampilkan maka bentuk dinosaurus secara artistik akan disesuaikan dengan benda yang mendukung terhadap bentuk anatomi bagian tubuh objek dinosaurus. Penulis memilih senjata sebagai media eksplorasi yang tepat terhadap bentuk objek dinosaurus. Senjata merupakan media eksplorasi yang nyata menjadi symbol karakter dinosaurus yang buas. Sehingga dalam karya ini penulis hendak membuat karya seni berupa senjata kapak untuk ditampilkan kembali kedalam bentuk hewan prasejarah yaitu dinosaurus. Menerapkan karakter hewan dinosaurus kedalam simbolisme emosi manusia dengan media berupa kapak ini. Adapun tujuan dari pembuatan karya ini adalah memberikan ketertarikan masyarakat Indonesia 
terhadap hewan purba yaitu dinosaurus. Dengan mengedepankan ikonik hewan prasejarah dinosaurus dengan tafsir baru. Sehingga timbul daya tarik visual senjata dengan tampilan yang lain dari pada yang lain.

\section{METODE PENCIPTAAN}

Metode yang digunakan dalam pembuatan karya seni ini menggunakan teori dari Gustami dengan 3 tahap 6 langkah dalam pembuatan karya seni teori penciptaan Gustami terdiri dari tiga tahap enam langkah penciptaan seni kriya. Pertama adalah tahap eksplorasi, yang terdiri dari 2 langkah, yaitu langkah melakukan pengembaraan jiwa, pengamatan lapangan, serta langkah penggalian sumber informasi dan penggalian landasan teori dan acuan visual. Kedua adalah tahap perancangan, yang terdiri dari 2 langkah, yaitu langkah penuangan ide ke dalam sketsa, serta langkah penuangan ide ke dalam model. Tahap yang ketiga adalah tahap perwujudan, yang terdiri dari 2 langkah, yaitu mewujudkan berdasarkan model, serta mengevaluasi tentang kesesuaian ide dan wujud produk yang bernilai seni, dan juga ketepatan fungsi.

\section{HASIL DAN PEMBAHASAN}

Kemampuan dalam membuat suatu bentuk karya yang inovatif dan menarik untuk para audience merupakan tuntutan yang mendasar dalam melahirkan karya baru yang tidak monotone dan terkesan hanya itu-itu saja. Bagi seorang pencipta karya tuntutan ini menjadi suatu treeger dalam mencari pemahaman baru mengenai suatu konsep dalam berkarya, salah satu contohnya adalah kemampuan menghubungkan suatu kecendrungan objek berkarya dan simbol yang ingin disampaikan. Salah satu cara yang sering digunakan adalah mencampurkan konsep visual kepada unsur simbolik yang dikehendaki seniman. Unsur ini merupakan bentuk pencarian seorang seniman tentang konsep sosial, emosi, maupun pengalaman pribadinya. Berbagai hal inilah yang hendak dibagi melalui konsep karyanya. Dalam pengkaryaan kali ini konsep utama yang hendak diwujudkan merupakan senjata genggam berupa kapak yang diberikan stilisasi hewan prasejarah dinosaurus. Karya ini merupakan bentuk penemuan mengenai konsep simbolisme karakter dinosaurus terhadap karakter emosional manusia, setiap hal yang dialami manusia memiliki tolak ukur terhadap bentuk-bentuk emosional tersendiri. Bentuk emosi ini menjadikan konsepsi dasar perwujudan karya melalui kecocokan bentuk objek dengan ekspresi visual yang sering digambarkan kedalam bentuk hewan prasejarah dinosaurus. Salah satu contohnya adalah bentuk ekspresi marah manusia dapat digambarkan sebagai hewan besar, ganas, bergigi tajam dan memiliki raut yang menyeramkan. Maka hewan prasejarah yang memiliki kecendrungan itu adalah jenis predator seperti Tyranosauru Rex atau sering disapa T-Rex. Tidak kita pungkiri bahwa dinosaurus jenis ini sering digambarkan sebagai dinosaurus yang garang dan pemarah. Fakta ini dapat menjadi dukungan terhadap tafsir mengenai emosi manusia dapat digambarkan sebagai hewan prasejarah seperti T-Rex.

Simbol merupakan suatu unsur penciptaan yang dibutuhkan dalam mengkomunikasikan tafsir atau maksud yang ingin disampaikan kepada orang lain. 
"Komunikasi manusia berlangsung melalui Pertukaran simbol serta pemaknaan symbol-symbol tersebut. Dan dibutuhkan konsep dari interaksi simbolik pada penekanan manusia langsung pada stimulus kedalam response, tetapi didasari pada pemahaman terhadap apa yang terasakan melalui penggunaan symbol, interpretasi, media pada akhirnya bermaksud mencapai kesepakatan bersama." Herbert Mead George (1998:38) Berdasarkan hal tersebut diatas, dibutuhkan pertukaran suatu symbol atau perasaan keintiman yang sama agar karya dapat menyampaikan ketertarikan yang sama dengan apa yang dirasakan seniman. Salah satu cara yang nyata adalah memunculkan suatu ikon yang dimaksud kedalam karya yang dibuat.

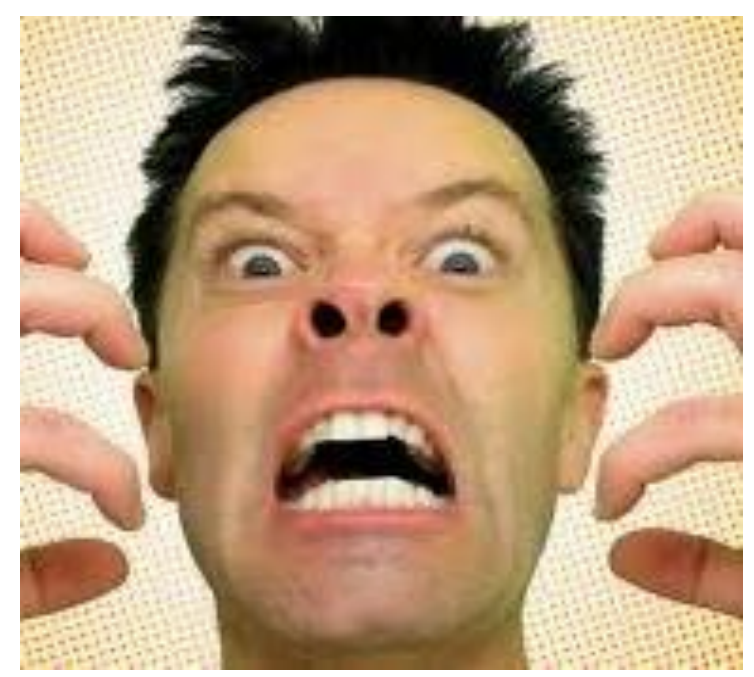

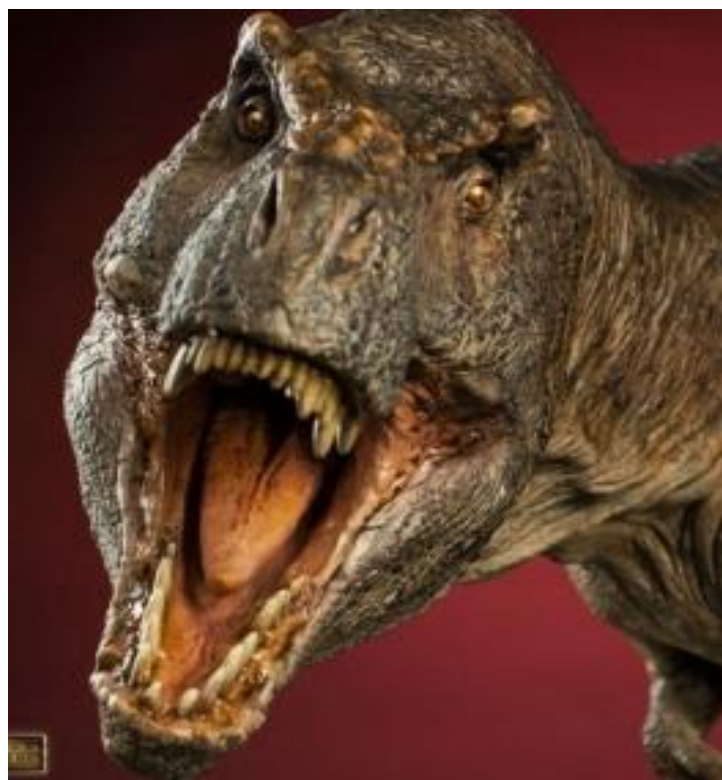

Gambar 1. Ekspresi wajah marah manusia dengan wajah Tyranosaurus Rex

Sumber:http://global.rakuten.com/en/store/hakatasmile/item/1009399/

Konsep simbolis yang didapat kan selanjutnya diolah kembali menjadi suatu bentuk baru dalam pengkaryaan untuk itu dibutuhkan media sebagai alat eksplorasi yang nyata. Penulis memilih objek senjata kapak sebagai media yang dirasa tepat dalam mewadahi konsep visual dan simbolisme tersebut. 


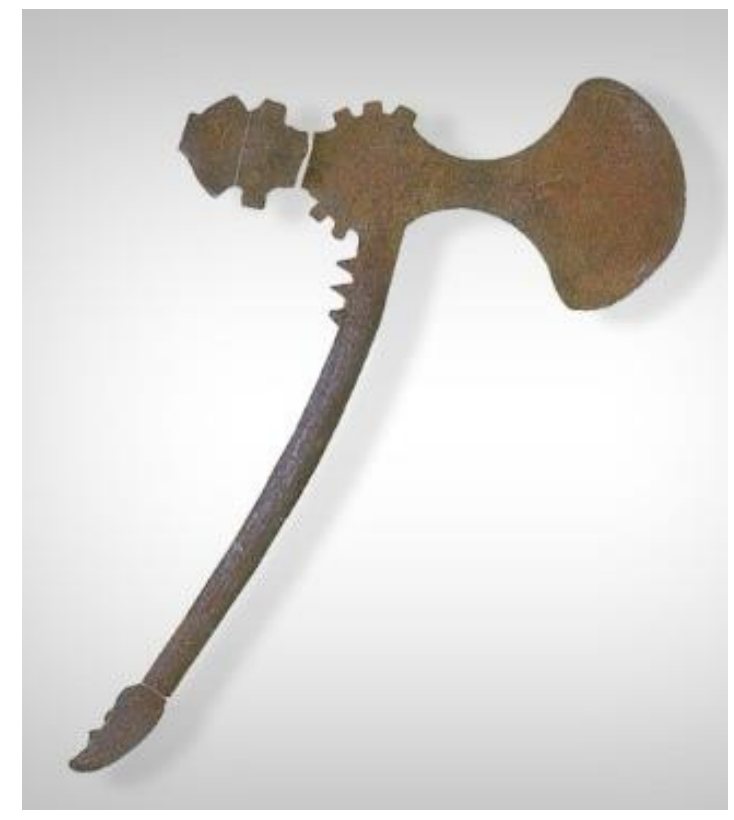

Gambar 2. Salah satu bentuk kampak purba

Kapak merupakan wujud senjata genggam yang mewakili kekuatan dengan unsur bilah tajam melengkung pada bagian depan diatas pegangan. Bentuk ini memungkinkan senjata tenaga yang kecil namun memiliki dampak tekanan yang tinggi melalui daya lenting tangan pemakai. Kapak juga memiliki bentuk kekhasan tersendiri dengan berbagai bentuk bilah yang vareatif menjadikan banyak pilihan untuk dieksplorasi. Tindakan nyata eksplorasi yang dilakukan adalah dengan menyatukan unsur anatomi dinosaurus kedalam bentuk kapak yang sesuai. Stilisasi ini menjadi inovasi visual yang baru untuk dinikmati audience sepagai pengalaman visual yang baru dengan konsep yang menarik.

Sketsa prototype karya:

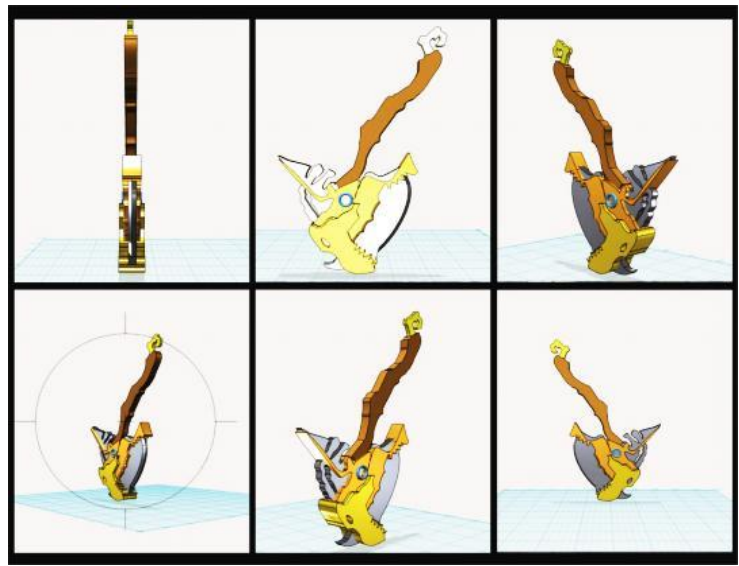

Gambar 3. Desain prototype 1 karya dalam 3D modeling.

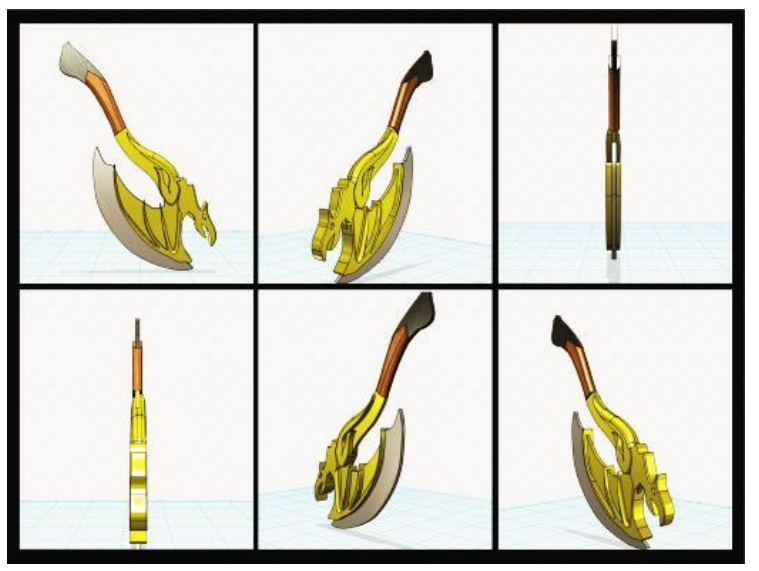

Gambar 4. Desain prototype 2 karya dalam 3D modeling.

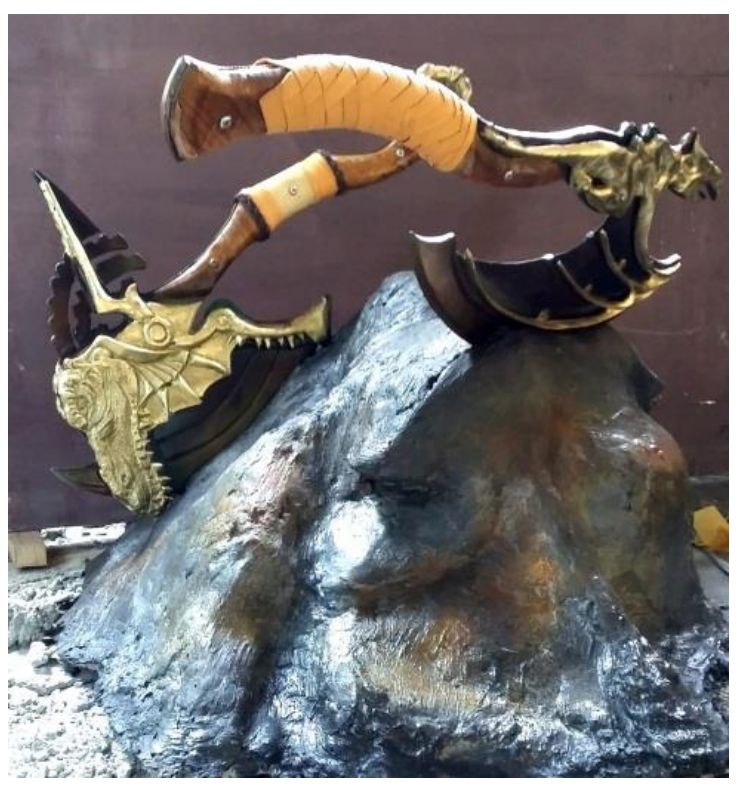

Gambar 5. Display Karya 


Sebuah karya yang dapat
memvisualkan karakteristik dari
perewujudan persamaan objek yang
dikemukakan dalam karya eksplorasi
merupakan tindakan nyata menangkap
fenomena seni yang ada. Karya yang
mengangkat wujud hewan prasejarah ke
dalam media baru merupakan aksi seni
dalam proses penciptaan karya seni yang
baru. Penciptaan karya berbasis
penggayaan terhadap suatu objek ini
merupakan upaya mempernalkan objek
simbolyang dimaksudterhadap masyarakat
Indonesia yang masih kurang minat
terhadap unsur-unsur bermuatan
pantologis seperti dinosaurus. Hewan
prasejarah yang berusaha divisualkan
adalah dinosaurus karena di samping nilai-
nilai simbolik di dalamnya terdapat potensi
untuk dikembangkan. Yaitu adalah edukasi
terhadap potensi sejarah dan objek
prasejarah menyangkut wilayah Indonesia
yang belum digali. Dinosaurus yang
diwujudkan tidak digunakan sebagai
ornamentasi tempelan saja namun
digunakan sebagai ikon seni
mempopulerkan kecintaan sejarah
terhadap masyarakat.

Selain pertimbangan artistik karena kapak ini memiliki fungsi yang nyata jika digunakan memiliki daya tarik yang luar biasa untuk diuji coba. Salah satunya adalah dengan memberikan kesempatan bagi audience jika ingin mencoba atau sekedar memegangnya. Sehingga tidak hanya melihat saja, namun audience dapat merasakan pengalaman yang sama. Para audience yang melihat disuguhkan karya seni kriya kayu yang tanpa disadari merupakan simbolisasi emosiaonal kedekatan antara emosionalisme manusia dan simbolisme karakter hewan prasejarah. Karya baru ini diharapkan akan menjadi alat baru dalam mengungkapkan tentang pemahaman seniman melalui penumuan pemikiran yang ingin disampaikan dengan media karya seni kriya.

\section{Karya 1}

Sebagai manusia dalam menjalani kehidupan harus memiliki suatu prinsip yang dipegang. Ibarat Kapak yang merupakan senjata genggam yang dalam pemakaianya harus dipegang atau digenggam. Dan ketika yang kita pegang adalah cerminan dari kebuasan yang merupakan gambaran diri tentang amarah yaitu raksasa purba Tyranosaurus Rex (TRex). Perwujudan Kapak ini akan menjadi media eksplorasi keintiman antara diri pribadi tentang pengendalian kebuasan yang ada dalam diri masing-masing. Bentuk amarah yang menjadi suatu senjata manusia dalam menghadapi berbagai godaan dalam menjalani kehidupan mulai dari munculnya amarah yang dapat dikendalikan hingga munculnya amarah yang dapat merusak apapun yang ada dihadapannya. Sehingga senjata kapak ini hanyalah perwujudan media yang dapat digunakan manusia sesuai apa yang dikehendakinya bisa menjadi baik ataupun menjadikanya lebih buruk. Karena pada dasarnya semua orang akan memburu amarahnya masing-masin 


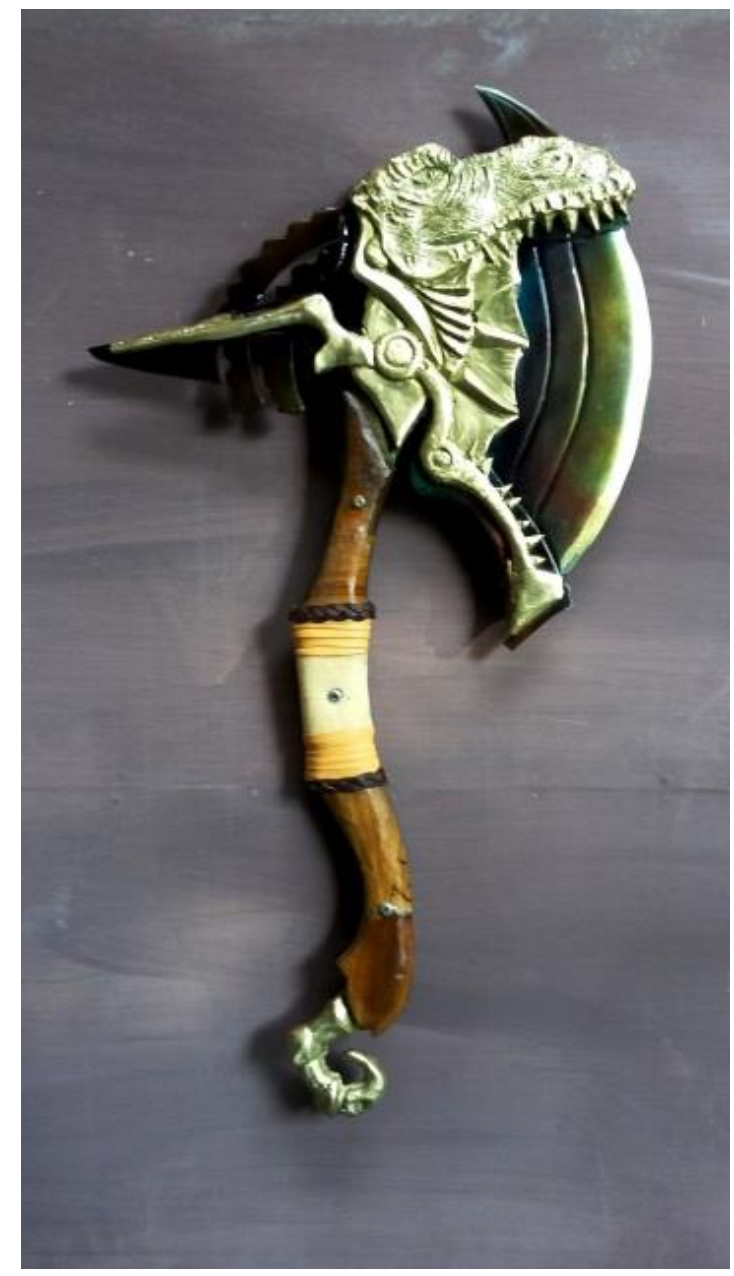

Gambar 6. Judul karya: Kapak "Pemburu Amarah" Dimensi : $75 \mathrm{~cm} \times 45 \mathrm{~cm} \times 2 \mathrm{~cm}$

\section{Karya 2}

Kapak merupakan senjata yang dapat digunakan untuk membelah objek atau benda padat. Namun bagaimana jika diumpamakan dapat membelah media yang tidak terlihat namun hanya dapat dirasakan seperti angin. Hal ini merupakan suatu bentuk perumpamaan terhadap suatu hal yang memiliki kehebatan yang luar biasa. Konsep itu menjadi suatu penggambaran bagaimana dulunya terdapat mahkluk darat yang dapat terbang membelah angin dan merajai langit. Bentuk sayap ini menjadi suatu simbol keberhasilan Pyteranodon (dinosaurus) melampaui kemampuanya dalam berevolusi dalam membentuk kemampuannya. Layaknya manusia dalam hal berevolusi akan ada saat dimana manusia akan melakukan suatu hal yang tidak mungkin seperti halnya membelah angin. Capaian inilah yang akan menjadi senjata manusia dalam hal memenuhii tujuanya melalui berbagai ketidak mungkinan.

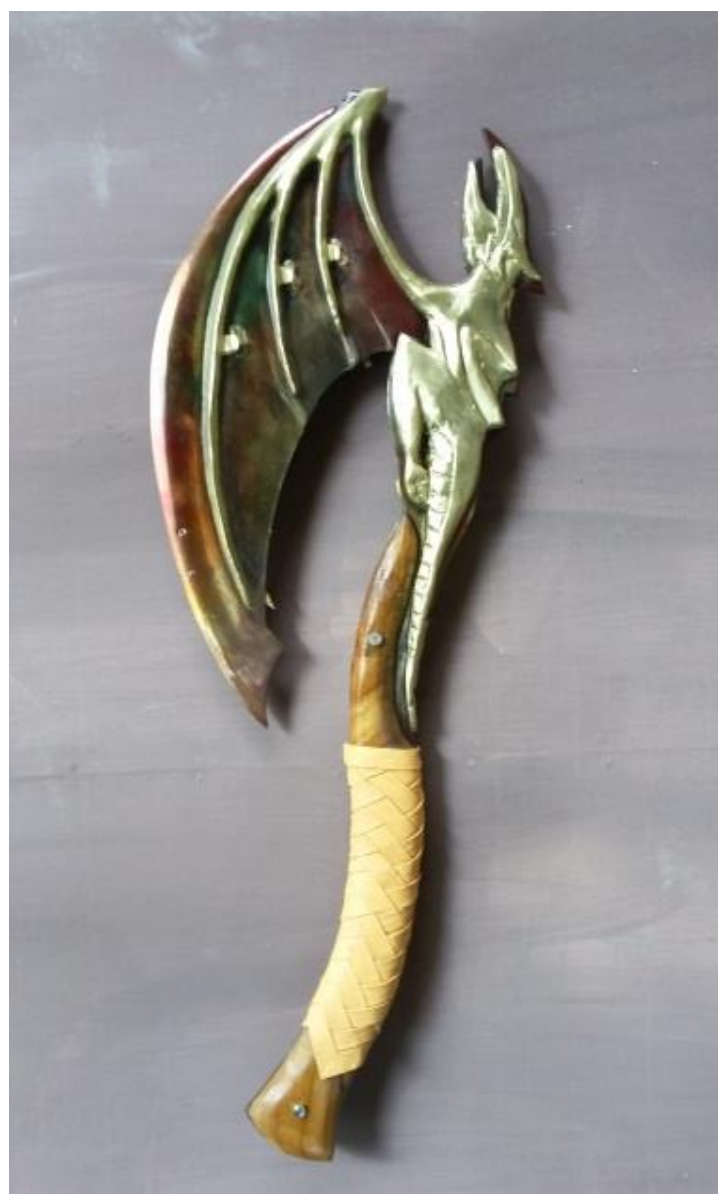

Gambar 7. Judul karya : Kapak "Pembelah Angin" Dimensi : $75 \mathrm{~cm} \times 45 \mathrm{~cm} \times 2 \mathrm{~cm}$

\section{PENUTUP}

Konsep yang dipilih adalah sebuah penemuan pemikiran mengenai penggambaran hewan prasejarah kedalam media pengkaryaan. Eksplorasi pemikiran yang dimaksudkan adalah perwujudan senjata kapak yang melibatkan simbolisasi 
emosional manusia dalam kehidupan. Karena bentuk emosional manusia memiliki kemiripan yang sama dengan karakter yang digambarkan dalam hewan prasejarah yaitu dinosaurus. Berbeda secara visual dan nilai filosofi ini akan mengantarkan pada ketertarikan simbol yang hendak dimunculkan. Mengingat bentuk hewan prasejarah ini meiliki keunikan untuk kembali dimunculkan sebagai pemahaman baru mengenai hubungan antara pesan pada suatu karya dan wujud simbol yang menarik untuk dilihat secara visual maupun sebagai penggugah imajinasi berfikir masyarakat saat ini. Karena memang ditujukan untuk mengganggu pemikiran mainstream masyarakat tentang karya seni dan kehidupan seseorang terlebih kemampuan emosional pribadi dalam menghadapi masalah hidup.

Terselesaikanya 2 buah kapak dengan bentuk hewan prasejarah ini yang memiliki nilai-nilai emosional melalui ubahan visual berupa dimasukkanya bentuk dinosaurus seperti T-Rex dan Pteranodon, Karya seni dan simbolisme kehidupan merupakan unsur penting pada karya ini. Komposisi ubahan inilah yang dirasa mampu membuat nilai artistik dari karya kapak ini muncul. Setiap audience yang melihat karya ini tentunya akan melihat konsep pemahaman terhadap unsur visual dalam bentuk baru seperti terangkum pada satu kemasan yang artistik. Masing- masing dari karya ini memiliki karakteristik yang berbeda dan disesuaikan dengan nilai-nilai dan pesan yang ada di dalamnya namun secara utuh karya ini memiliki satu garis besar visual tentang pesan simbolisme itu sendiri. Melihat hal tersebut maka dapat dikatakan karya penciptaan ini berhasil diwujudkan sesuai apa yang telah direncanakan sebelumnya.

\section{DAFTAR PUSTAKA}

Feldman, Edmund Burke.(1993), Practicial Art Cricticsm, Chicago: Paper Back.

Gustami, SP. (2008), Nukilan Seni Ornamen Indonesia, Jurusan Kriya Fakultas Seni Rupa Institut Seni Indonesia Yogyakarta, Yogyakarta

Herbert Mead George.(1998), Teory of Symbol, New York City: Daily Paper.

Langer, Susanne K.(1957), Philosophy In a New Key: Study In The Symbolism. Havard University Press, North California.

Nurmianto, Eko.(2008), Ergonomi: Konsep Dasar dan Aplikasinya, Edisi Kedua, Guna Widya, Surabaya ,Indonesia.

Sachari, Agus.(1989), Estetika Terapan, Nova, Bandung, Indonesia

\section{WEBTOGRAFI}

Sumber Unduhan Gambar:

http://www.egidino.com/2010/07/pengert ian-dinosaurus_20.html http://global.rakuten.com/en/store/hakata -smile/item/1009399/

http://s.kaskus.id/r540/images/201502/28 /367805-20150228032143.html

http://pinterest.com/armor/ydgdgshdbuar t-leather.html 